\title{
Juridical Deed Review Of The Cooperation Agreement To Build Handover (Build Operate And Transfer) Bot Between Government And Private Sector
}

\author{
Desi Wulan Anggraini ${ }^{1}$, Bagus Langgeng Prasetiyo $^{2}$ and Anis \\ Mashdurohatun $^{3}$
}

Abstract. The purpose of this study was to: 1) To determine and analyze the Agreement in order to handover a build (Build Operate And Transfer) BOT between government with Private Sector. 2) To determine and analyze the Regulation No. 19 of 2016 there are no relevant provisions of the cooperation agreement made in the form of a notarial deed but in implementing cooperation agreements and there are other legal regulations. The data used in this study are primary data, secondary data and data that can support tertiary study, which was then analyzed by descriptive analytical method.

Based on the results of data analysis concluded that: 1) Deed in the agreement to transfer (Build Operate And Transfer / BOT) before the formation of Regulation No. 19 of 2016, has complied with the requirements valid agreement of Article 1320 of the Civil Code sehigga positions of the legislation. Notary deed in agreement wake up in order to transfer (Build Operate and Transfer) BOT after the entry into force of Regulation No. 19, 2016 a requirement valid agreement beyond the provisions of the Civil Code, and if it is not done then there will never been considered although qualify valid agreement of Article 1320 of the Civil Code. The legal consequences deed of cancellation of the parties shall make a certificate into a build to transfer (Build Operate Transfer / BOT) lose their authenticity, the cancellation of the agreement unilaterally because defaults are not eligible void Article 1266 of the Civil Code, can be regarded as an act against the law because it is not based on good faith and such cancellation shall be requested to the trial judge.

Keywords: Judicial Review; Government Cooperation Agreement; Build Operate and Transfer And Deed.

\section{Introduction}

Infrastructure development or physical development is largely determined by the model of funds and land. In the construction of the parties has a large capital but did not have enough land to build, on this condition the emergence of mutual need between one party with another party which gave rise to the employment relationship that gave birth to the agreement cooperation, including a cooperation agreement between the government and the private sector to utilize the goods belonging to the area with one of the models or forms of cooperation carried out in the form of waking to Unidirectional or Build Operate Transfer (BOT).

BOT also for private projects, meaning that the parties involved in the indvidu with private individuals or private. Wake agreement to transfer a form of cooperation agreement made between the rights holder on the ground with investors, whereby investors are granted the right to erect a building for the duration of the agreement

\footnotetext{
${ }^{1}$ Students of Master of Notary Law, Faculty of Law Universitas Islam Sultan Agung and Financial Asset Management Agency (BPKAD) Yogyakarta, email: dera9997@gmail.com

2 Students of Master of Law, Faculty of Law Universitas Islam Sultan Agung email baguslanggengp7@gmail.com

${ }^{3}$ Faculty of Law Universitas Islam Sultan Agung
} 
and transfer of ownership of the building to the holders of land rights after the agreement expires. ${ }^{4}$

The local government gain some benefit when choosing a wake patterns in order to transfer to utilization of their land through the construction of assets by the private sector due to limited funding capacity such obvious is because it does not need to pay to build on his land assets.

Private sector participation can be directed at projects that require a large investment, such as construction of highways, oil and gas, dams, construction of the mall, airport expansion, as well as power plants and can also be directed at infrastructure projects that do not require funding that is too large, such as the renovation market, terminal , truck stops, rest areas, resort and others. ${ }^{5}$

BOT existence is to meet the needs of the practice, in which on the one hand the land owners need funds to build, but the funds are not available. On the other hand, investors need land or land to build on. The two sides then met and the needs outlined in the BOT agreement. In general, the agreement made by the parties in the form of BOT agreement designed in accordance with the will of the parties themselves, along Covenant, made not contrary to the laws or rules of law, both formal and substantive aspects of the (substance). ${ }^{6}$

The Indonesian Law provisions mengantur BOT agreement, which essentially didsarkan in Article 33 paragraph 3 of the constitution of 1945, which was then elaborated in Act No. 5 of 1960 on Basic Agrarian Law. Then, as an agreement, then the BOT agreement is based on the third book of the Civil Code of Engagement current utilization area property is no longer contained in the form of a notarial deed but made by deed under hand.

Based on the description and the facts above, the necessary studies are structured to assess these problems because it is closely related to the condition of the validity of the agreement of cooperation covered by notarial deed, so the authors are interested in examining the position of a notary deed in perjanjiann a build in order to transfer and without legal effect deed cancellation of the parties to the deed of transfer into a build order, and contained in the form of research with the title: "Juridical Deed Review Of The Cooperation Agreement To Build Handover (Build Operate And Transfer) BOT Between Government And Private Sector".

From the description of the background of the above, the formulation of a problem that can be submitted are as follows: The position of the notarial deed in order to transfer into a build (Build Operate and Transfer) BOT between the government and the private sector? What are the legal consequences of the parties to the deed of cancellation of the deed to transfer into a build (Build Operate and Transfer) BOT between the government and the private sector?

\section{Research methods}

\footnotetext{
${ }^{4}$ Anita Kamilah, 2013, Bangun Guna Serah (Build Operate and Transfer) BOT, Membangun Tanpa Harus Memiliki Tanah, (Perspektif Hukum Agraria, Hukum Perjanjian dan Hukum Publik), Cetakan Pertama, Bandung, p.6.

${ }^{5}$ Ridwan saleh, 2009, Kajian Tentang Kerjasama Pembiayaan dengan Sistem Build Operate Transfer (BOT) di kabupaten Pekalongan, Undip, Semarang, p.42.

${ }^{6}$ Irawan Soedarjo, 2003, Kepastian Hukum Hak Atas Tanah Di Indonesia, Arloka, Surabaya, p. 60.
} 
The approach used in this study is primarily descriptive analytical approach. Descriptive analysis is research that describes an analysis of the existing findings. ${ }^{7}$ The approach by descriptive analysis in this study, is peraturann approach in terms of legislation and legal norms in accordance with the existing problems.

\section{Results and Discussion}

\subsection{Build Cooperation Agreement To Deliver (Build Operate and Transfer) BOT between the government and the private sector}

Etymologically, the agreement can be interpreted in which one or more bind himself to one or more, whereas according to the Dictionary of Indonesian Language, an agreement is an agreement (written or oral) made by two or more parties, each agreement will comply with what is mentioned in the agreement. Article 1313 of the Civil Code states a contract or agreement can be interpreted as an act by which one or more persons bind himself to one or more other people.

Full and complete understanding of the understanding or agreement the definition from vary greatly. To facilitate the understanding of the agreement and determine the scholars expressed the opinion as follows: According to R. Subekti, the agreement is an event where a promise to others, or where the two men promised each other to implement something. According Sudikno Mertokusumo, the agreement is a legal relationship between two or more parties based on an agreement to give rise to legal consequences.

Understanding above shows that in an agreement that will lead to a legal relationship of the parties to make an agreement. Each party is bound to one another and the rights and obligations between the parties that made the agreement. The legal relationship between the parties is possible because the engagement is born of an agreement which is one source of the birth of the engagement, while the source of the birth of another engagement is legislation.

The meaning of the cooperation of local governments with third parties, in Government Regulation No. 50 Of 2007 on the Implementation of the Cooperation Region (hereinafter referred to as Regulation No. 50 of 2007) which states regional cooperation is an agreement between the Governor and the Governor or the Governor and Regent / Mayor or between Regent / Mayor with Regent / Mayor of others, or the Governor, Regent / Mayor with third parties, which is made in writing and creates rights and obligations. Although PP No. 50 of 2007 does not mention the word treaty, but the phrase "in writing and creates rights and obligations" in Article is meaningful agreements for cooperation between local government and the third party that begins with the deal. Definition of the cooperation agreement the government and third parties is clearly stated in Presidential Decree Number 13 Of 2010 on Amendment of Presidential Decree Number 67 Of 2005 on Government Cooperation with Business Entities in the Provision of Infrastructure, that the agreement is a written agreement for the provision of infrastructure between Ministry / Chairman of the Institution / Head of Business Entities established through a public auction. ${ }^{8}$

\footnotetext{
7 Soerjono Soekanto dan Soleman B. Taneko, 2001, Hukum Adat Indonesia, Raja Grafindo Persada, Jakarta, p 172.

${ }^{8}$ Legislation in question is written rules established by state institutions or officials authorized and binding in general, as required by Article 1 (2) and Article 7 of Act No. 10 Of 2004 on the Establishment of Legislation.
} 
Based on some explanation regarding the definition of a cooperation agreement between local government and third parties of the above, it can be concluded that there are some basic things in the formation of a cooperation agreement between the local government by a third party that must be considered, which include:

- Beginning with the agreement containing rights and obligations.

- Made in writing.

- Party cooperation should be a legal entity.

Supervision and control of a cooperation agreement in the area, given the duty and authority to the Minister of the Interior to issue Permendagri 19, 2016, to further regulate the formation of asset management. Permendagri 192016 is the authority granted Regulation No. 27 Of 2014, to issue a policy related to asset management area. As defined in Regulation No. 19, 2016 that asset management authority is the Regional Head area. ${ }^{9}$

To further the authority of the Head of Region in cooperation agreements asset management area in the form of wake up in order to transfer and get up to deliver to the implementation set forth in the agreement, which was signed by the governor / regent / mayor with partner woke up to the transfer of authority to sign the legal act civil in nature principally as cooperation agreement must be in the hands of governors / regents / mayors in charge of the care of the highest in the area of local governance. The legal responsibility will continue to stick both inside and outside the court, and this is evident in case of civil disputes involving area then sued the governor, regent or mayor.

Legally, with reference to the provisions of Act No. 32 of 2004 which provides regional, status as an autonomous legal entity through its organs (regional head) to organize and manage the affairs of government in the interests of the local community. Thus, all legal actions, both public and private that would burden the area with all the legal bonds must be drawn up and signed by the head of the region. Meanwhile, if the agreement was signed by the person or the official was not authorized, then the legal consequences of the agreement is null and void.

Agreement to Build To Deliver (Build Operate and Transfer) BOT is a concept in which the project is built on the full cost of private companies, some private companies or cooperation with State and after it is built, operated by contractor and after stages of the operation is completed as specified in the agreement, then do the transfer of the project to the government as the owner of the project.

Testament sense Build To Deliver (Build Operate and Transfer) BOT in Regulation No. 19 of 2016 is the use of the property of the area in the form of land by the other party by means of building and / or the means of its facilities, and then utilized by the other party within a specific time period agreed, henceforth handed back the land and building and / or the means of its facilities after the expiry of Regulation No. 19 of 2016 set the related demand planning and budgeting, procurement, receipt, storage and distribution, usage, administration, utilization, security and maintenance, assessment, removal, transfer, guidance, monitoring and control. ${ }^{10}$

The scope of the regulation are among regulating utilization, which is of such utilization is the utilization of goods belonging to areas that are not used for the implementation of tasks and functions of SKPD and optimization of possessions area with no change in ownership status.

\footnotetext{
${ }^{9}$ Than Thong Kie, 2001, Studi Notariat dan Serba-Serbi Praktek Notaris, Buku I, ichtiar Baru, Jakarta, p. 162.

${ }^{10}$ Ibid, p.28.
} 
As a result of non-fulfillment of requisite forms of agreements that have been specified in the legislation, Habib Adjie explained that the agreement forms abuse of which has been determined by the Act may result in canceled absolute where the agreement has never been considered, and no base again for the parties to prosecute or sue each other in any way or any form.

Of these, according to the author of a notarial deed in the agreement wake up in order to transfer (Build Operate and Transfer) BOT can be thought never existed not because it is caused not qualify the validity of the agreement according to the Civil Code, but formally no longer comply with the laws and regulations and do not have position as the likely authentic deed. From the research, there is a cooperation agreement wake to transfer (Build Operate and Transfer) BOT Yogyakarta government made with the form under the hand before the enactment of Regulation No. 19, 2016 remains in force binds the parties because Permendagri 19, 2016 can not be applied retroactively to the agreement that has been done before, the cooperation agreement under the hand still has no legal status as a deed that binds both parties elayaknya legislation, so that what is listed on the contents of the deed to the strength of the evidence that is perfect for not denied by the parties, but to have the strength as evidence in court, the agreement may be registered under the arm or warmekking by a notary in order to have the strength of evidence like the authentic act ${ }^{11}$.

Based on the above, it is understood that by the provisions of treaties the utilization of the property of the area is set in the form of a notarial deed then in the formation of the agreement the utilization of the property of the area should be made by virtue of the provisions of Regulation No. 19 of 2016 as a condition for the validity of the cooperation agreement of local governments, but the agreement must also pay attention to the rules contained in UUJN and regulations governing general agreement that the Civil Code as a supplementary rule.

\subsection{As a result of the Deed Law Against Cancellation Parties To Build Partnership Deed (Build Operate Transfer) BOT Between Local Governments With Private Party.}

A good agreement can be implemented when the parties meet such performance has been agreed without the injured party. But sometimes agreements are not performing well due to breach of contract by one of the parties. Tort actions bring consequences to the occurrence of the aggrieved party's right to sue the parties in default to provide compensation, so that the law is expected that no injured party for breach of contract. Associated with the deed of cancellation of the parties, it can be judged that the deed of cancellation begins with the default Private Sector who then carried out the unilateral termination of the government stated in the deed of agreement that the first party may terminate the agreement unilaterally. Contract cancellation or termination of the agreement in this discussion is devoted to revoke the agreement because the private sector has been in default, not because they do not qualify subjectively or objectively in the agreement. Based on this research, a cooperation agreement between the City Government of Yogyakarta PT. Perwita Karya, since 2009 the management of the terminal was officially taken over by the Department of Transportation Yogyakarta government because PT. Perwita Karya is not able to meet

\footnotetext{
${ }^{11}$ Habib Adjie II, 2013, Kebatalan dan Pembatalan Akta Notaris, Cetakan Kedua, Refika Aditama ,Bandung, p. 67.
} 
its obligations to develop supporting facilities including a shopping center in the complex Giwangan as set out within the scope of the cooperation agreement. ${ }^{12}$

On the basis of the default Yogyakarta City Government has decided a cooperation agreement cancellation of Notarial Deed No. 04, dated March 10, 2009 before the Tri Agus Heryono, $\mathrm{SH}$, notary in Sleman, with the agreement of both parties have mutually agreed and unanimously to turn off and mambatalkan akta- deed of agreement and resolve the rights and obligations of each to appoint an independent team, namely PT. Satyatama Graha Tara to conduct calculations based on market or economic value that has been done by PT. Perwita Karya and binds the parties pledged promise and accept the work of the independent team which is a final decision, but the PT. Perwita cited their work are corporate assets are not recognized and assessed by the City Government of Yogyakarta and independent team, which then filed a lawsuit. Associated with the deed of cancellation of the parties, it can be judged that the deed of cancellation begins with the default Private Sector who then carried out the unilateral termination of the government stated in the deed of agreement that the first party may terminate the agreement unilaterally.

Termination of the agreement of the Government of Yogyakarta city in accordance with the act of default from the PT. Perwita Karya is the appropriate scope of the treaty, it can not continue the construction of supporting facilities including a shopping center in the Passenger Terminal Type A Giwangan, so with all the legal consequences Yogyakarta government can terminate the agreement unilaterally as stipulated in article 18 paragraph (5) Deed No. 02 dated 9 September 2002 regarding the Development and Management of Passenger Terminal type A Giwangan Yogyakarta.

Cancellation of the agreement aimed at bringing the two sides back to the situation before the agreement was held. It therefore means that by law can be considered there was never any engagement between the parties to the cooperation agreement, which was therefore void is with complete accounts payable regarding a cooperation agreement was also considered never existed or in other words to remove, so the deed of cancellation of the deed of agreement cooperation will give a result of the agreement deed no longer have a position as the authentic act and deed of cancellation of the agreement if it can be proven based on bad faith, then the deed of cancellation also does not have proper authenticity of a notary deed. tort and restitution to the District Court of the city of Yogyakarta until then finally submitted to appeal to the Supreme Court (MA) and otherwise won the case. Against the decision of the Supreme Court (MA), Yogyakarta City Government filed a judicial review which was won also by PT. Perwita Karya. Associated with the deed of cancellation of the parties, it can be judged that the deed of cancellation begins with the default Private Sector who then carried out the unilateral termination of the government stated in the deed of agreement that the first party may terminate the agreement unilaterally. ${ }^{13}$

Although the terms cancel itself has stated in the deed of agreement, in which the first party may waive the provisions of Article 1266 of the Civil Code to everything related to the termination of the agreement according to the article so that the termination is done first party to notify in writing the second, but the terms canceled in the agreement still must meet three requirements termination under article 1266 of the Civil Code. Termination of the agreement of the Government of Yogyakarta city in accordance with the act of default from the PT. Perwita Karya is the appropriate scope

12 Article 2 Deed No. 02, September 9, 2002 on the Development and Management of Passenger Terminal Type A Giwangan Yogyakarta.

${ }^{13}$ Ibid, p. 46. 
of the treaty, it can not continue the construction of supporting facilities including a shopping center in the Passenger Terminal Type A Giwangan, so with all the legal consequences Yogyakarta government can terminate the agreement unilaterally as stipulated in article 18 paragraph (5) Deed No. 02 dated 9 September 2002 regarding the Development and Management of Passenger Terminal type A Giwangan Yogyakarta. ${ }^{14}$

Termination of the agreement by the Government of Yogyakarta as outlined in the deed of cancellation also have consequences for the tort that occurs when the TS. Perwita work is admitted to the defaults and is unable to fulfill his achievements as stated in the deed of agreement. So in this case PT. Perwita Karya is getting a waiver of the breach committed by the approved and agreed in the deed of cancellation of the agreement made, thus the cancellation certificate can also be regarded as a new agreement between the City Government of Yogyakarta PT. Perwita Karya with each of the parties to agree and reach a consensus to resolve the rights and obligations of each. Waiver of the breach of contract by PT. Perwita Karya above means also that the Government of Yogyakarta has waived his right to collect receivables from PT. Perwita Karya by asserting no longer want their achievements and to waive his right to payment or the fulfillment of the agreements, the relationship of debts in the agreement be made clear by the deed of cancellation of the agreement. deed of cancellation of the deed of agreement will give a result of the agreement deed no longer have a position as the authentic act and if the deed of cancellation of the agreement.

\section{Closing}

\subsection{Conclusion}

Based on the research results can be concluded as follows:

- The notarial deed in agreement wake up in order to transfer (Build Operate and Transfer) BOT local government before the establishment of Regulation No. 19 of 2016, based on freedom of contract are binding as law for the parties because in the manufacturing process and the formation of such deed has complied with the requirements validity of the agreement pursuant to Article 1320 of the Civil Code so that the positions of authentic evidence that a perfect legal force and the regional cooperation agreement also serves as legislation. The notarial deed in the wake agreement to transfer (Build Operate and Transfer) BOT after the entry into force of Regulation No. 19 of 2016, is a prerequisite for a valid agreement outside the provisions of the Civil Code in the implementation of regional cooperation agreement and shall be set in the form of a notarial deed.

- The legal consequences notarial deed which was canceled by the deed of cancellation of the parties will make such deed loses its authenticity so into a build to transfer (Build Operate and Transfer) BOT shall be deemed to have never occurred and the parties can not incur liability, in the case of cancellation of the agreement unilaterally due to breach of contract, which is not eligible void Article 1266 of the Civil Code, can be regarded as an unlawful act for unilateral cancellation is not based on good faith and act in accordance with the principles of propriety and prudence and the cancellation.

\footnotetext{
${ }^{14}$ Article 129 paragraph (1), subsection 157 (1), 179 (2) and 230 (2) Minister Regulation No. 19 Of 2016 on Guidelines for Management of Regions.
} 


\subsection{Suggestion}

- For Notary in making making authentic deeds as evidence of perfect binding is required trait of prudence and thoroughness by asking and attention to detail on what is presented by the parties to the deed in accordance with the provisions set forth by the legislation, especially Code civil Code and the Law on Notary, and also provisions in the realm of public law when, where one party is the government.

- For the party should in entering into a pact to always acting in good faith and honest of the deed to the implementation of the agreements so that an agreement can end well, especially with a shared understanding of the agreement is to optimize the property of the area in order to generate added value of revenue will used as a service for the greatest prosperity and welfare of the community.

\section{Bibliography}

[1] Anita Kamilah, 2013, Bangun Guna Serah (Build Operate and Transfer) BOT, Membangun Tanpa Harus Memiliki Tanah, (Perspektif Hukum Agraria, Hukum Perjanjian dan Hukum Publik), Cetakan Pertama , Bandung

[2] Habib Adjie II, 2013, Kebatalan dan Pembatalan Akta Notaris, Cetakan Kedua Refika Aditama, Bandung

[3] Irawan Soedarjo, 2003, Kepastian Hukum Hak Atas Tanah Di Indonesia, Arloka, Surabaya

[4] Ridwan saleh, 2009, Kajian Tentang Kerjasama Pembiayaan dengan Sistem Build Operate Transfer ( BOT) di kabupaten Pekalongan, Undip, Semarang

[5] Soerjono Soekanto dan Soleman B. Taneko, 2001, Hukum Adat Indonesia, Raja Grafindo Persada, Jakarta

[6] Than Thong Kie, 2001, Studi Notariat dan Serba-Serbi Praktek Notaris, Buku I, Ichtiar Baru, Jakarta

[7] The Book of Civil Law (Statute 1847 Number 23). Act No. 23 Of 2014 regarding Regional Government (State Gazette of the Republic of Indonesia Of 2014 Number 244, Supplement to the State Gazette of the Republic of Indonesia Number 5587).

[8] Act No. 2 of 2014 on the Amendment of Act No. 30 of 2004 concerning Notary (State Gazette of the Republic of Indonesia Of 2014 Number 3, State Gazette of the Republic of Indonesia Number 5491).

[9] Government Regulation No. 27 Of 2014 concerning Management of State / Regional (State Gazette of the Republic of Indonesia Of 2014 Number 92, Supplement to the State Gazette of the Republic of Indonesia Number 5533). 